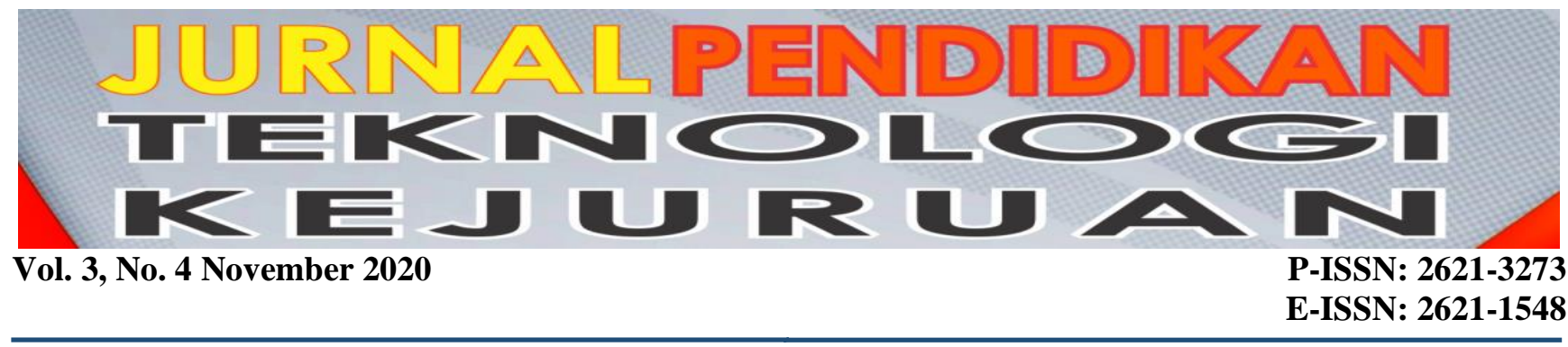

\title{
Student Perspectives Toward Pre-Service Teachers Competencies
}

\author{
Junil Adri ${ }^{1}$, Ambiyar $^{2}$, Refdinal $^{3}$, Unung Verawardina ${ }^{4}$, Vivi Efrianova $^{5}$, Abrar Tanjung $^{6}$, \\ Ferdiansyah $^{7}$, Fani Keprila Prima ${ }^{8}$ \\ 1,2,3 Teknik Mesin, Fakultas Teknik, Universitas Negeri Padang \\ ${ }^{4}$ Pendidikan Teknologi Kejuruan, Fakultas Teknik, Universitas Negeri Padang \\ ${ }^{5}$ Tata Rias dan Kecantikan, Fakultas Pariwisata dan Perhotelan, Universitas Negeri Padang \\ ${ }^{6}$ Teknik Elektro, Fakultas Teknik, Universitas Lancang Kuning \\ ${ }^{7}$ Teknik Informatika dan Komputer, Fakultas Teknik, Universitas Negeri Padang \\ ${ }^{8}$ Teknik Bangungan, Fakultas Teknik, Universitas Negeri Padang \\ "Corresponding author, e-mail: juniladri@ft.unp.ac.id ${ }^{1}$
}

\begin{abstract}
This study aims to determine how students' perceptions of the competence of pre-service teachers in the PPLK program at SMK Negeri 1 Padang. Aspects that are observed in basic educational competencies are pedagogic, personality, professional, and social. This research is descriptive. Observations were made for three years. The population in the study were all class $X$ students of SMK Negeri 1 Padang. Sampling was done using the random sampling technique using Slovin's formula. The findings of the study showed that the average competency of preservice teachers in the PPLK program at SMK Negeri 1 Padang for three years of observation was in a good category. The research findings recommend that there is a need for improvement in the pedagogical and social fields of preservice teachers. Teacher readiness to teach will affect the achievement of learning objectives. Besides, social competence is needed to establish communication and interaction between pre-service teachers and teachers in schools and students. There needs to be an improvement in learning related to teaching preparation for pre-service teachers specifically to emphasize pedagogic and social competencies.
\end{abstract}

Keyword : Competence, Teacher, Pedagogic, Personality, Professional, Social

\section{INTRODUCTION}

Education is an important aspect of human life and is known as a basic need that must be met to support life (Spencer, Tomblin, \& Gantz, 2012). Education aims to increase human dignity and to produce higher quality human beings (Sugestiyadi, 2011). Besides, education aims to ensure the implementation and continuity of the nation and state development (Hanafi, 2014). This confirms that education is an important aspect in a country, including Indonesia. Various efforts have been made to improve the quality of education, namely through updating and perfecting the teaching curriculum, improving the quality of teaching staff, student motivation, and the provision of adequate facilities and infrastructure (Tahir, Mustafa, \& Yassin, 2009). The teacher is one of the factors that affect the quality of education (Sugiyanto, Slamet, \& Sugiyono, 2016). The quality of a teacher determines the success of his students who will become the nation's successor (Destiana \& Utami, 2017). Indonesian government policies are contained in Indonesian Government
Regulation Number 19 of 2005 concerning Indonesian National Education Standards, which in essence, every education staff, especially teachers, must have four basic competencies, namely: pedagogical competence, professional competence, personal competence, and social competence. By mastering these four basic competencies, it is hoped that teachers can realize their performance appropriately and effectively as educators (Cohen et al., 2020).

Universitas Negeri Padang (UNP) is one of the educational institutions in the field of education in Indonesia which is tasked with providing guidance and guidance to qualified pre-service teachers. To improve the quality of its graduates, UNP sets the Program Pengalaman Lapangan Kependidikan (PPLK) as a compulsory subject for all undergraduate students. Students of the Faculty of Engineering Department of Mechanical Engineering UNP Mechanical Engineering Education study program is one of the study programs that carry out PPLK in Vocational High Schools (SMK) both inside and 
outside West Sumatra Province. During implementing PPLK, pre-service teachers interact with students in teaching and learning activities in class. From these interactions arise students' perceptions about the competence of pre-service teachers in carrying out tasks (Sutkin et al., 2017). Every interaction that occurs between two humans will cause perceptions, as well as interactions between students and pre-service teachers as educators (Wilson-Mitchell \& Handa, 2016). Perception arises after students as objects see, hear, or feel something then interpret it (Hoogenes et al., 2015). Students' perceptions of student competence as pre-service teachers greatly influence the success of these students in running PPLK (Adri, Jalinus, Ambiyar, Jama, \& Giatman, 2020). Based on preliminary observations, many cases state that students' perceptions of PPLK student competence as teacher candidates are still not good. The results of interviews that the author conducted with several students at SMK Negeri 1 Padang, some of them were happy to be taught by PPLK students, some by students who were added ignorant, and some others who felt dissatisfied because PPLK students did not understand the material presented so students could not understand. The readiness of the teacher and the way in which the learning is carried out by the teacher in the classroom is important to pay attention to to achieve learning objectives (Buxton, Phillippi, \& Collins, 2015). PPLK students who act as teachers at SMK Negeri 1 Padang must meet the set standards. It is necessary to research the educational competencies possessed by pre-service teachers to determine the weaknesses of teacher education.

\section{METHOD}

This study uses a descriptive research method with a quantitative approach because the data obtained is in the form of numbers and resolved by statistical counting (Soendari, 2012). The population in this study were all students of class $X$ at SMK Negeri 1 Padang. The research was conducted for three years, namely 2017, 2018, and 2019. Sampling used Slovin's formula (Rukajat, 2018). The number of samples in this study amounted to 349 class X students at SMK Negeri 1 Padang with various fields of expertise. SMK Negeri 1 Padang in the field of Mechanical Engineering provides 5 opportunities each year for the PPLK pre-service teacher program.

Basic educational competencies are some abilities that teachers must have to reach the professional teacher level (Anwar, 2018). The object under study is the competence of PPLK students as pre-service teachers. The instrument used in this study was in the form of a closed questionnaire whose answers had been grouped. After the data was collected through the research instrument, the editing and data conversion was then carried out, then descriptive statistics were carried out (Soendari, 2012).

\section{RESULT}

Data on the competence of PPLK students as pre-service teachers at SMK Negeri 1 Padang were collected through a research questionnaire consisting of 4 indicators, namely pedagogic, personality, professional, and social, which had been tested for validity and reliability. Research questionnaire sheets were given to 349 grade X students at SMK Negeri 1 Padang. The pedagogic, professional, personality and social questionnaires have five alternative answers, namely strongly agree, agree, disagree, disagree, and strongly disagree with the respective answers to scores of 5,4,3,2, and 1 (Nazir, 1988).

\section{A. Pedagogic}

Pedagogic indicators consist of educational foundations, lesson planning, learning administration, motivation theory and knowing students, learning evaluation (Schimbeno, Bosle, Stegmeier-Petroianu, Etminan, \& Hoffmann, 2019) with 14 statement items. The findings of the study showed that the mean value of pedagogic competence in 2017 was 3.21 , in 2018 was 3.45 and in 2019 was 3.36. Student responses assess that prospective teacher is still unable to recognize and provide motivation in the implementation of classroom learning.

\section{B. Personality}

Personality competence indicators consist of a foundation of self-confidence, self-concept, responsibility, tolerance, spirituality, creativity, communication, and innovation (Omid, Haghani, \& Adibi, 2018). The number of statement items in this variable is 10 question items. The findings of the study showed that the mean value of personality competence in 2017 was 3.81 , in 2018 was 3.45 and in 2019 was 3.62. Student responses to the personality competencies of pre-service teachers who practice teaching at SMK Negeri 1 Padang show good results. Pre-service teachers have confidence and a good attitude in their role as teachers.

\section{Professional}

Professional competence indicators are mastery of material and learning theory, management of learning and curriculum, mastery of media and technology, development of educational insights 
(Anwar, 2018) with 8 statement items. The findings of the research showed that the mean value of professional competence in 2017 was 3.58 , in 2018 it was 3.57, and in 2019 was 3.43. Students feel that preservice teachers who are in PPLK at SMK Negeri 1 Padang are quite professional in carrying out their duties as teachers. In the learning process, the teacher can display a professional and serious attitude.

\section{Social}

Indicators of social competence are social participation, social tolerance, and nondiscrimination (Rahim, Anitha, Govindaraj, \& Laila, 2017) with 6 statement items. The findings of the study showed that the mean value of social competence in 2017 was 3.46, in 2018 was 3.34 and in 2019 was 3.41. From these results, it was explained that students assessed that pre-service teachers in the PPLK process at SMK Negeri 1 Padang were not fully able to socialize with students. Students feel there is discrimination in the classroom. Teachers tend to pay more attention to smart students.

The results showed that the perceptions of class $\mathrm{X}$ students towards the competence of PPLK students as pre-service teachers at SMK Negeri 1 Padang still need improvement in teaching education for preservice teachers.

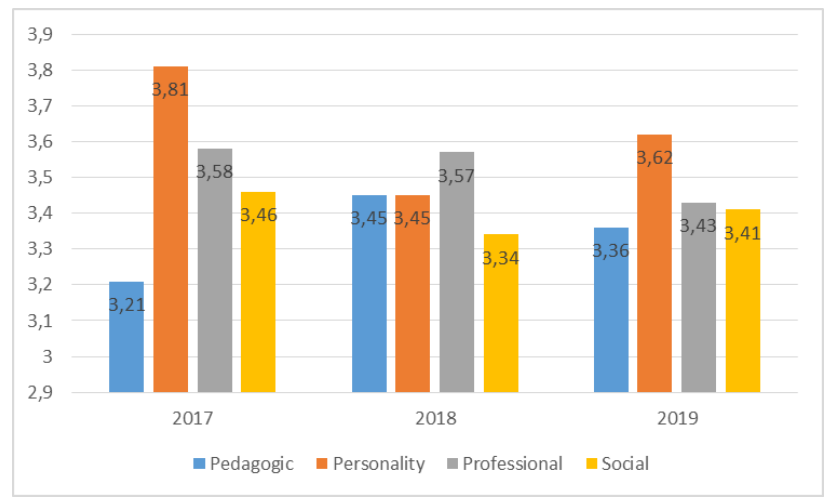

Figure 1. Graph of the percentage of student perceptions of the competence of PPLK students as pre-service teachers

According to the students, the objectives of PPLK activities were achieved well by each PPLK student. PPLK activities are teacher training candidates designed to prepare pre-service teachers to master teacher skills so that after completing their education and being appointed as teachers, they are ready to carry out their duties and responsibilities as teachers. From the graph, it can be seen that pedagogic competence and social competence score low compared to other competencies. The implementation of the PPLK program as practical teaching training for pre-service teachers in schools is expected to provide experience with real conditions in the school environment. PPLK students' competence in carrying out their duties and responsibilities as teachers after graduation is undoubted because they have mastered basic educational competencies. The results of the research regarding the achievement of basic educational competencies of PPLK students can be seen in Figure 2.

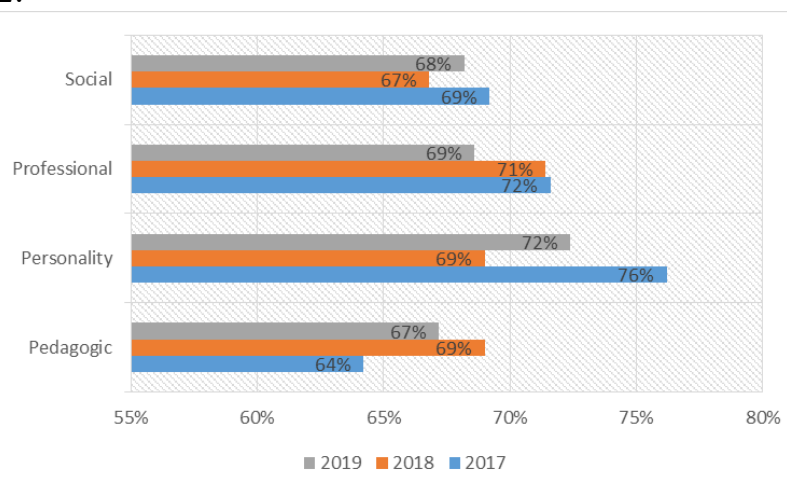

Figure 2. Graph of PPLK student competency achievements as preservice teachers

The achievement of the four domains of basic educational competencies for pre-service teachers in the PPLK program from the point of view of students at SMK Negeri 1 Padang shows an average pedagogic competence of $67 \%$. The average personality competency is $73 \%$. The average professional competence is $71 \%$ and the average social competence is $68 \%$. There are two competencies whose level of achievement is still below $70 \%$, namely pedagogical competence, and social competence.

\section{DISCUSSION}

A person's view of an object or event gives rise to an understanding for the individual which is created from the interaction of the five senses (Anggraini, 2016). PPLK activities are teacher training candidates designed to prepare pre-service teachers to master teacher skills. After completing their education and being appointed as teachers, they are ready to carry out their duties and responsibilities as teachers. From the results of research conducted in 2017 to 2019 at SMK Negeri 1 Padang, the mastery of basic educational competencies by pre-service teachers in the PPLK program is still $70 \%$. Pedagogic competence which is a fundamental competence in education 2017 received a percentage of $64 \%$, in 2018 it was $69 \%$, and in 2019 was $67 \%$. From the instruments provided, students assessed that the pedagogical competence of the Gugu candidates in the PPLK program was still not at an average of $67 \%$. Analysis of instrument items found that pre-service teachers have not been able to carry out each learning step according to the design that has been made. Besides, the design of the learning program that was made was not adapted to the characteristics of students who were in SMK Negeri 1 Padang. The 
results of this study are the same as the results of Karea research entitled Pedagogic Competence And Indonesian Language Competence Pre-Service Teacher Of Elementary Program explains that the pedagogical competence of prospective Indonesian language teachers is still low (Karea, 2019). The same difficulty for pre-service teachers is the suitability of student characteristics with the design of the learning program (Darnius, 2016). Learning basic educational competencies obtained in lectures is different from the real situation at school. Suhandani and Julia research stated that dominant pedagogical competencies will be obtained based on experience (Suhandani \& Julia, 2014). Learning planning for each school will be different according to the background of the student, school, and environment. Learning planning also includes the selection of learning methods to be implemented (Habibullah, 2012). From the results of this study, the curriculum for pursuing special teaching methods requires an additional introduction to the school environment and student characteristics to pre-service teachers. This additional implementation can be done in collaboration with schools that are partners in the PPLK program.

Teachers are a source of basic information and role models for students (Buxton et al., 2015). Personality competencies consist of a foundation of confidence, self-concept, responsibility, tolerance, spirituality, creativity, communication, and innovation (Modi, Anshu, Gupta, \& Singh, 2015). A prospective teacher must be able to control himself and be a role model for students. The results of research in 2017 the achievement of teacher candidate personality competencies was $76 \%$, in 2018 it was $69 \%$ and in 2019 it was $72 \%$. The average competence of this person is $73 \%$. These results explain that pre-service teachers in interaction with students are confident enough, have a self-concept, and position themselves as teachers in guiding students during learning. The weak indicator in this competence is communicative. Self-matching between pre-service teachers and students requires a long process. The results of this study are similar to the research conducted by Saglam in 2011, explaining that creating a personality as a teacher must be based on experience. As long as you become a teacher, your personality as a teacher will be formed (Huda, 2017).

The profession of a teacher is professional (Fahdini, Mulyadi, Suhandani, \& Julia, 2014). Professional competence is mastery of material and learning theory, management of learning and curriculum, mastery of media and technology, development of educational insights (Ningrum, 2009). Analysis of research results in 2017 the achievement of professional competence of pre- service teachers in the PPLK program was $72 \%$, in 2018 it was $71 \%$ and in 2019 it was $69 \%$. The average achievement of this professional competence is at $71 \%$. Student responses in professional competence to pre-service teachers in the PPLK program at SMK Negeri 1 Padang have not yet mastered the material presented. Trinova's research in 2012 explained the importance of mastering material for teachers in teaching in the classroom. Mastery of the material will create an effective and fun classroom atmosphere for students (Trinova, 2012).

Learning in the classroom involves teachers and students. The interaction of teachers and students makes communication delivery of learning, this is called social competence. Social competence includes social participation, social tolerance, and non-discrimination (Ashsiddiqi, 2012). The analysis of the results of the research on the achievement of social competence for pre-service teachers in the PPLK program at SMK Negeri 1 Padang in 2017 was $69 \%$, in 2018 it was $67 \%$, and in 2019 it was $68 \%$. The average for this social competence is $68 \%$. Student responses to this social competence are quite low. Students assess that pre-service teachers in the PPLK program at SMK Negeri 1 Padang are less able to adjust to students. Often there are communication errors between teachers and students. Pre-service teachers have not been able to create conducive and communicative classes. Learning tends to go in one direction. In the 2014 Puluhulawa research, it explained the importance of social relationships between teachers and students in the classroom. Important interactions in learning. The teacher must be able to create a communicative classroom to create a pleasant learning atmosphere (Puluhulawa, 2014).

The Mechanical Engineering Education study program provides training to become a teacher in several educational courses. The PPLK program aims to provide teachers with a real-world experience of education. The experience in the PPLK program is expected to increase readiness to become a teacher. The results of this study indicate the achievement of basic educational competencies possessed by preservice teachers who practice the field at SMK Negeri 1 Padang. The Mechanical Engineering Education study program as a medium for producing teacher candidates must emphasize four basic educational competency concepts so that pre-service teachers are skilled as professional teachers (Musfah, 2012). Increasing competencies that get low-performance scores can be done by observing the target school before implementing the PPLK program for preservice teachers and this is implemented in debriefing activities for pre-service teachers in the study program. 


\section{Conclusion}

The PPLK program provides real experiences to pre-service teachers. Mastery of four basic educational competencies is very important in creating conducive learning. The mean of students' views on feeling pedagogic competence was at the percentage of $67 \%$, personality competence $73 \%$, professional competence $71 \%$, and social competence was $68 \%$. The low achievement of pedagogic competence results in the readiness of pre-service teachers in carrying out learning. The low achievement of social competence resulted in an uncommunicative learning atmosphere. To solve the problem of the mechanical engineering education study program, the prospective teacher must give the task of monitoring and introducing the target school before implementing the PPLK program for preservice teachers.

\section{REFERENCES}

Adri, J., Jalinus, N., Ambiyar, A., Jama, J., \& Giatman, M. (2020). Pengaruh Kesiapan Mengajar Terhadap Sikap Mengajar Calon Guru Muda. Jurnal Vokasi Mekanika (VoMek), 2(2), 15-21.

Anggraini, I. S. (2016). Motivasi Belajar dan Faktor-Faktor yang Berpengaruh: Sebuah Kajian Pada Interaksi Pembelajaran Mahasiswa. Premiere Educandum: Jurnal Pendidikan Dasar dan Pembelajaran, 1(02).

Anwar, M. (2018). Menjadi guru profesional: Prenada Media.

Ashsiddiqi, H. (2012). Kompetensi sosial guru dalam pembelajaran dan pengembangannya. Ta'dib: Journal of Islamic Education (Jurnal Pendidikan Islam), 17(01), 61-71.

Buxton, M., Phillippi, J. C., \& Collins, M. R. (2015). Simulation: a new approach to teaching ethics. $J$ Midwifery Womens Health, 60(1), 70-74. doi: 10.1111/jmwh. 12185

Cohen, A., Sur, M., Weisse, M., Moffett, K., Lancaster, J., Saggio, R., . . . Thammasitboon, S. (2020). Teaching Diagnostic Reasoning to Faculty Using an Assessment for Learning Tool: Training the Trainer. MedEdPORTAL, 16, 10938. doi: 10.15766/mep_2374-8265.10938

Darnius, S. (2016). Identifikasi Kesulitan Guru Dalam Mengimplementasikan Kurikulum 2013 Dengan Pendekatan Saintifik Di Kelas Tinggi Gugus Mangga Kecamatan Jaya Baru Banda Aceh. Jurnal Pesona Dasar, 2(4).

Destiana, B., \& Utami, P. (2017). Urgensi kompetensi pedagogik guru vokasional pada pembelajaran abad 21. Elinvo (Electronics, Informatics, and Vocational Education), 2(2), 211-222.

Fahdini, R., Mulyadi, E., Suhandani, D., \& Julia, J. (2014). Identifikasi Kompetensi Guru sebagai Cerminan Profesionalisme Tenaga Pendidik di Kabupaten Sumedang. Mimbar Sekolah Dasar, 1(1), 33-42.
Habibullah, A. (2012). Kompetensi pedagogik guru. EDUKASI: Jurnal Penelitian Pendidikan Agama dan Keagamaan, 10(3).

Hanafi, I. (2014). Pendidikan Teknik dan Vokasional:: Menggali Pengalaman Sukses Institusi BiNational di Negeri Jiran, dari Konsep hingga Implementasi: Deepublish.

Hoogenes, J., Mironova, P., Safir, O., McQueen, S. A., Abdelbary, H., Drexler, M., ... Sonnadara, R. R. (2015). Student-led learning: a new teaching paradigm for surgical skills. Am J Surg, 209(1), 107-114. doi: 10.1016/j.amjsurg.2014.08.037

Huda, M. (2017). Kompetensi Kepribadian Guru dan Motivasi Belajar Siswa. Jurnal penelitian, 11(2), 237-266.

Karea, S. (2019). Pedagogic Competence and Indonesian Language Competence Pre-Service Teacher of Elementary Program.

Modi, J. N., Anshu, Gupta, P., \& Singh, T. (2015). Teaching and Assessing Clinical Reasoning Skills. Indian Pediatr, 52(9), 787-794. doi: 10.1007/s13312-015-0718-7

Musfah, J. (2012). Peningkatan kompetensi guru: Melalui pelatihan dan sumber belajar teori dan praktik: Kencana.

Nazir, M. (1988). MetodePenelitian. Jakarta: Ghalia Indonesia.

Ningrum, E. (2009). Kompetensi Profesional Guru dalam Konteks Strategi Pembelajaran. Bandung: Buana Nusantara.

Omid, A., Haghani, F., \& Adibi, P. (2018). Emotional Intelligence: An Old Issue and a New Look in Clinical Teaching. Adv Biomed Res, 7, 32. doi: $10.4103 / 2277-9175.225926$

Peraturan Pemerintah Indonesia Nomor 19 Tahun 2005

Puluhulawa, C. W. (2014). Kecerdasan emosional dan kecerdasan spiritual meningkatkan kompetensi sosial guru. Hubs-Asia, 10(1).

Rahim, A. A., Anitha, P. M., Govindaraj, G. M., \& Laila, K. V. (2017). Identifying core competency areas to assess communication skills among interns at a tertiary teaching hospital in southern India. Natl Med J India, 30(6), 332-336. doi: 10.4103/0970258X.239076

Rukajat, A. (2018). Pendekatan Penelitian Kuantitatif: Quantitative Research Approach: Deepublish.

Schimbeno, V., Bosle, C., Stegmeier-Petroianu, A., Etminan, N., \& Hoffmann, K. (2019). Competence-based teaching and learning in the outpatient clinic: development of a clinical elective in ambulatory medicine. GMS J Med Educ, 36(4), Doc36. doi: 10.3205/zma001244

Soendari, T. (2012). Metode Penelitian Deskriptif. Bandung, UPI. Stuss, Magdalena \& Herdan, Agnieszka, 17.

Spencer, L. J., Tomblin, J. B., \& Gantz, B. J. (2012). Growing up with a cochlear implant: education, vocation, and affiliation. J Deaf Stud Deaf Educ, 17(4), 483-498. doi: 10.1093/deafed/ens024

Sugestiyadi, B. (2011). Pendidikan Vokasional Sebagai Investasi. Diambil dari http://staff. uny. ac. id/sites/default/files/131571720/PENDIDIKAN\% 
20VOKASIONAL\%

20INVESTASI\%

20Kompetetion. doc.
20SEBAGA\%

20 Sutu\%

Sugiyanto, S., Slamet, S., \& Sugiyono, S. (2016). Pengembangan kompetensi profesional berkelanjutan dosen vokasi pada pendidikan vokasional di Lampung. Jurnal Pendidikan Vokasi, 6(3), 292-304.

Suhandani, D., \& Julia, J. (2014). Identifikasi Kompetensi Guru Sebagai Cerminan Profesionalisme Tenaga Pendidik Di Kabupaten Sumedang (Kajian Pada Kompetensi Pedagogik). Mimbar Sekolah Dasar, 1(2), 128-141.

Sutkin, G., Littleton, E. B., Kanter, S. L., Cianciolo, A. T., Chen, X. P., Cope, A., \& Koschmann, T. (2017). Teaching, Learning, and Performance in the Surgical Workplace: Insights From the Examination of Intraoperative Interactions. Teach Learn Med, 29(4), 378-382. doi: 10.1080/10401334.2017.1384732

Tahir, L. M., Mustafa, N. Q., \& Yassin, M. H. M. (2009). Pendidikan Teknik Dan Vokasional Untuk Pelajar Berkeperluan Khas. Journal of Educators \& Education/Jurnal Pendidik dan Pendidikan, 24.

Trinova, Z. (2012). Hakikat Belajar dan Bermain Menyenangkan bagi Peserta Didik. Al-Ta Lim Journal, 19(3), 209-215.

Wilson-Mitchell, K., \& Handa, M. (2016). Infusing Diversity and Equity Into Clinical Teaching:

Training the Trainers. J Midwifery Womens Health, 61(6), 726-736. doi: 10.1111/jmwh. 12548 